\title{
The Impact of Faba Bean Theft in Rural Ethiopia: To Dispute or to Reside Together in Harmony?
}

Tesfanesh Zekiwos-Gichamo

Rural Development and Natural Resource Management

Masters program

Swedish University of Agricultural Sciences (SLU).shegazek@gmail.com

Uppsala, Sweden

Erik Karltun

Deparment of Soils and Environment

Swedish University of Agricultural Sciences (SLU)

Uppsala, Sweden

Motuma Tolera

Wondo Genet College of Forestry

Hawassa University

Ethiopia

Linley Chiwona-Karltun

Deparment of Urban \& Rural Development

Swedish University of Agricultural Sciences (SLU)

Uppsala, Sweden

Contact author: Linley Chiwona-Karltun: linley.karltun@sol.slu.se;

\begin{abstract}
Previous studies have shown that faba bean cultivation in Ethiopia has been abandoned, in part, because of widespread theft. In order to solve this problem, many rural and farming communities agreed to formulate by-laws using an existing local institution called Iddir to punish the thieves and to support farmers in their efforts to start growing faba beans again. However, in some areas farmers have not yet switched back to growing faba beans. The overall aim of this study was to examine the factors that affected the reintroduction, or lack thereof, of faba bean growing. The results revealed that the effects of villagization, fear of conflict, small landholdings, population growth and migration, and lack of women participation in decision making were among the factors that affected the non-adoption of bean growing. Moreover, unemployment, poverty, and delinquent behaviours have also been found to be contributing factors.
\end{abstract}

Keywords: conflict, faba bean, food security, institutions, theft, villagization 


\section{The Impact of Faba Bean Theft in Rural Ethiopia - Zekiwos-Gichamo, Karltun, Tolera, and Chiwona-Karltun}

\section{Introduction}

The faba bean (Vicia faba $L$ ) is known as fava bean, broad bean, field bean, horse bean and bell bean (Duc et al., 2008). It is vital for human consumption in Ethiopia and other regions such as the Middle East, the Mediterranean region, and China. The faba bean is also used as animal feed in more industrialized areas, like Europe and the southern region of the United States (Duc et al., 2008, Muehlauer \& Tullu, 1997). China is the world's largest producer of the faba bean, followed by Ethiopia and Egypt (Duc et al., 2008).

Faba bean is one of the major food legumes grown in the Ethiopian highlands and is an important staple in the diet of Ethiopian people (CIAT, 2008). According to an Ethiopian Ministry of Agriculture and Rural Development (MoARD, 2003) report, the faba bean is essential for domestic consumption as well as export for foreign exchange. The report indicated that the government has been trying to increase total productivity to increase the amount of export while continuing to satisfy domestic consumption. Ethiopia exports faba beans mainly to Djibouti, Yemen, and Israel (MoARD, 2003). As the faba bean has high nutritional value, it is considered to be a suitable substitute for meat and milk (Muehlauer \& Tullu, 1997).

In Ethiopia, people with an Orthodox religious background have a strong culture with regards to diet, which is prepared by pulse crops. ${ }^{1}$ Especially during fasting time, food is prepared by pulses such as chick peas, split peas, faba beans and lentils (CIAT, 2008). Compared to peas, the price of faba beans is much more affordable (Duc et al., 2008).

The use of the faba bean is not only limited for human and animal consumption, it is categorized among grain legumes that are effective in nitrogen fixation (Agegnehu, Ghizaw, \& Sinebo, 2006; Lindemann \& Glover, 2003; Matthews \& Marcellos 2003). The faba bean is considered to be 'one of the best nitrogen fixers' (Amanuel, Kühne, Tanner, \& Vlek, 2000), and it has been shown that incorporating leguminous crops in rotation is useful to increase soil fertility and to decrease fertilizer expenditure (Matthews and Marcellos, 2003)

Out of total world fertilizer consumption, Sub-Saharan Africa accounts for only one percent (USDA, 2005). In most low income countries, including Ethiopia, the use of chemical fertilizer is very low due to limited foreign exchange and lakc of available inputs for production of chemical fertilizers (USDA, 2005; MoARD, 2010). Like other low income countries, Ethiopian farmers are dependent on fertilizer that is imported from abroad. However, imported fertilizer is expensive and is sometimes unavailable in the market for small scale rural farmers (Howard, Said, Molla, Diskin, \& Bogale,1995; Fufa \& Hassan 2006; Amanuel et al., 2000). 


\section{Rationale and problem statement}

Ongoing studies ${ }^{2}$ focusing on soil management in Ethiopia have shown that fertility is decreasing. This is due to the lack of nitrogen-fixing legumes in the crop rotation practices of the area (Lemenih, 2004; Karltun, Röing de Nowina, Chiwona-Karltun, \& Berisso, 2008). Earlier studies indicated that in the past farmers were practicing crop rotations such as wheat, maize, sorghum, and legumes, especially the faba bean ( Vicia $\mathrm{faba}^{3}$ ) (Chiwona-Karltun, Mulugeta, Tolera, Berisso, \& Karltun, 2009; Lemenih, 2004). However, over time the cultivation of faba beans had been abandoned. This has had a negative impact not only on soil fertility, but also on household livelihoods and food security. Also mentioned as a possible reason for the refusal of farmers in the study area to grow beans is widespread faba bean theft (before it is ready for harvest) and the potential conflict in local communities that arose from this (Karltun et al., 2008).

In order to curb bean theft, the people who are living in the area formulated collective (agreed upon by all) by-laws and identified the Iddir as a means of enforcing the by-laws. Traditionally, an Iddir is a local burial association organized by a group of people who elect a chairperson and cashier. The cashier collects money and puts it in a bank or holds it until needed to help people who have lost a family member. Hence, it is a type of informal insurance. People chose to work with the Iddir because it historically was inclusive; nearly all of the local people are members of at least in one Iddir. No one wants to be excluded from this local institution as it plays such a substantial role in their day-to-day lives.

However, there were indications that although most of the farmers were once again growing the bean, one of the areas had refused to reintroduce it (Karltun et al., 2008). The aim of this study, then, was to evaluate faba bean reintroduction activities and to assess the factors that affected reintroduction. In addition to this, the study examined the cause of changing crop patterns, which was the absence of leguminous, nitrogen-fixing plants.

\section{Local Institutions in Rural Ethiopia}

In most low-income countries, formal institutional frameworks are weak in providing social welfare. As a result, most people are insecure socially, economically, and politically (Wood \& Gough, 2006). In Ethiopia, local institutions such as family and kinship structures, customs, traditions, and social norms are very important (Adal 1999, Mammo, 1999; Pankhurst \& Hailemariam, 2000). On a more organized level, in addition to the Iddir, there are other local attempts to improve the welfare of rural peoples and communities in Ethiopia, such as: (1) the $I q q u b$, which, like the Iddir, is an informal way of saving money among a group of households living the in same village, the funds of which are used in times of need or to start a business; (2) the Debo, is a work-sharing group during busy times, like during a harvest, in which people share work for no monies but the person requesting the help is expected to pay for food and 


\section{The Impact of Faba Bean Theft in Rural Ethiopia - Zekiwos-Gichamo, Karltun, Tolera, and Chiwona-Karltun}

drink; and (3) the Mahaber, which is an informal network of about ten families, mostly associated with the Orthodox Church, in which food preparation for feasts during holy days (which may last for several days) is communally shared (Adal 1999; Pankhurst \& Hailemariam, 2000). These institutions have served the communities for a very long time and their traditions and functions are passed down from one generation to the next (Mammo, 1999). These institutions are respected by local society, have considerable power, and they are widespread household livelihood strategies in Ethiopia.

Even if these local institutions are given less attention by scholars than institutions created by the state (Pankhurst, 2001), they have direct and indirect effects on socio-economic activities of families and communities in many societies. Wolde-Giorgis (1999) pointed out that Iddirs are involved in natural resource management, such as protecting forests, grasslands and water resources (Wolde-Giorgis, 1999). Wolde-Giorgis argued that it is good to encourage and involve grassroots level knowledge in order to enhance food security and natural resources management. In addition to this, Pankhurst (2001) and Adal (1999) stated that local institutions are playing a significant role in Ethiopian rural development related to information sharing, resource mobilization, and conflict resolution. While local institutions are playing a significant role in Ethiopian rural development, the study by Hundie (2010) revealed that they alone could not be effective in conflict management. The study emphasized the importance of government intervention to work together with these institutions to provide a 'locally motivated institutional framework' (Hundie, 2010).

\section{Theft and Dispute in Agricultural Communities}

In rural areas of societies of Africa and elsewhere, crops theft, cattle raiding and thievery of other agricultural products were mainly related to poverty, and sometimes used as a means of expressing opposition to unemployment and low wages (Fafchamps \& Minten 2003; Shakesheff, 2002; Schechter, 2007). Many rural poor were using crop theft as a risk coping strategy during times of temporary poverty (Fafchamps and Minten 2003). Fafchamps and Minten (2003) argued that the rural poor in many countries steal crops for personal consumption during bad times. For example, Schechter (2007) cited poverty was as one of the reason thieves commit the crime in rural Paraguay.

Based on studies by Aaron Brooks (1986) and Schechter (2007), farmers were reluctant to have thieves arrested and to take further legal action because they are afraid that the thieves will come back and take revenge in return. So the farmers preferred not to take any action. At the same time, they stated that the laws were very weak and were not good enough to protect them. Similarly, the study by Schechter (2007) indicated that only a few victims of theft reported to the police for legal action. They were not punished, even if the farmers caught the thief while thieves were stealing their property. Schechter (2007) stated that 'more of a crop is stolen when it is 
planted on a plot along a footpath, and that the crop fields which were far away from the farmer's home were more vulnerable to theft than the fields which were near to the home.

There is nothing new about theft from agricultural operations, and the relationship of farm crime to poverty. Shakesheff (2002) showed that when employment opportunities was low, rural poor were forced to steal both crops and wood in rural Herefordshire (England) several centuries ago. The rural poor engaged in crop theft to meet the basic necessities of their family. Moreover, Shakesheff (2002) argued that rural people also used crop and wood theft as a means of protest against low wages and high unemployment. Theft is still regarded as a survival action of the poor (Scott, 1985). Both men and women, especially widows, who no longer have husbands or a supporter participate more frequently in crop theft. In the past, most crop theft was for immediate consumption rather than for sale.

Where there is lack of legal enforcement, rural farmers use different strategies, mostly informal control in order to limit theft. In rural Paraguay, as the study by Schechter (2007) indicated, farmers give gifts and promise to continue in the future to give gifts to the person that they believe to be a thief in order to limit theft. Schechter (2007) argued that a person who is trustworthy receives fewer gifts than the person who is not trustworthy. Another strategy was monitoring the farm during the night. Even if there were various challenges, Karltun et al (2008) pointed out that in rural Ethiopia local institutions were playing a great role in controlling crop theft.

In Malawi, female food producers now prefer to grow bitter cassava rather than sweet cassava due to theft. Based on a study by Chiwona-Karltun, Tylleskär, Mkumbira, GebreMedlin, \& Rosling (2000), 90\% of interviewed women stated that cultivating bitter cassava was a strategy to minimize theft. The last resort for farmers was to abandon both cultivation of certain crops and the rearing certain animals due to fear of theft (Karltun et al., 2008; Schechter, 2007). In turn, this greatly affects investment decisions of farmers and of the wellbeing of their families (Schechter, 2007).

\section{Materials and Methods}

\section{Study area}

The study was conducted in Beseku Ilala peasant association in South Central Ethiopia. It is located between $7^{\circ} 20^{\prime}$ and $7^{\circ} 25^{\prime} \mathrm{N}$ and $38^{\circ} 45^{\prime}$ and $38^{\circ} 55^{\prime} \mathrm{E}$ and $240 \mathrm{~km}$ south of the capital city, Addis Ababa (Figure 1). Under the current governmental administrative system, Beseku Ilala peasant association is located in the Arsi Negelle district, East Shewa Zone of the Oromia Regional State. 
Arsi Negelle district is bordered by Arsi Zone to the East, Shashamene district to the South, Seraro district to the Southwest, Southern Nations, Nationalities' and peoples' Regional state to the West, and Adami Tullu district to the North. There are 35 peasant association and 3 urban kebeles (i.e., small, administrative units, like a neighbourhood or ward in a city) in Arsi Negelle district. According to Ethiopia's Central Statistics Authority (CAS) 2008 Population and Housing census survey, the population in Arsi Negelle district (Wereda) was 264,314. Out of the total population of the district 80 percent and 20 percenrt were living in rural and urban area respectively (CSA 2008).

Based on the local administrative system, Beseku Ilala peasant association is divided into 61 Gotes $^{3}$; and in each Gote there are 30- 34 households (Beseku Peasant Association, 2009). The population in Beseku Ilala peasant association in 2007 was 12,078 with a household having 6 members on average (CSA 2008). Agriculture is the main livelihood for the people who are living in this area. Crop production and livestock rearing are the major farming activities in Beseku. The major crops grown in this area are maize, wheat, sorghum, potatoes, and barley. Cattle, horse, donkey, sheep and goat are important livestock, which are used as draught power and for sale to generate income (Chiwona-Karltun et al., 2009; Tolera et al., 2008).

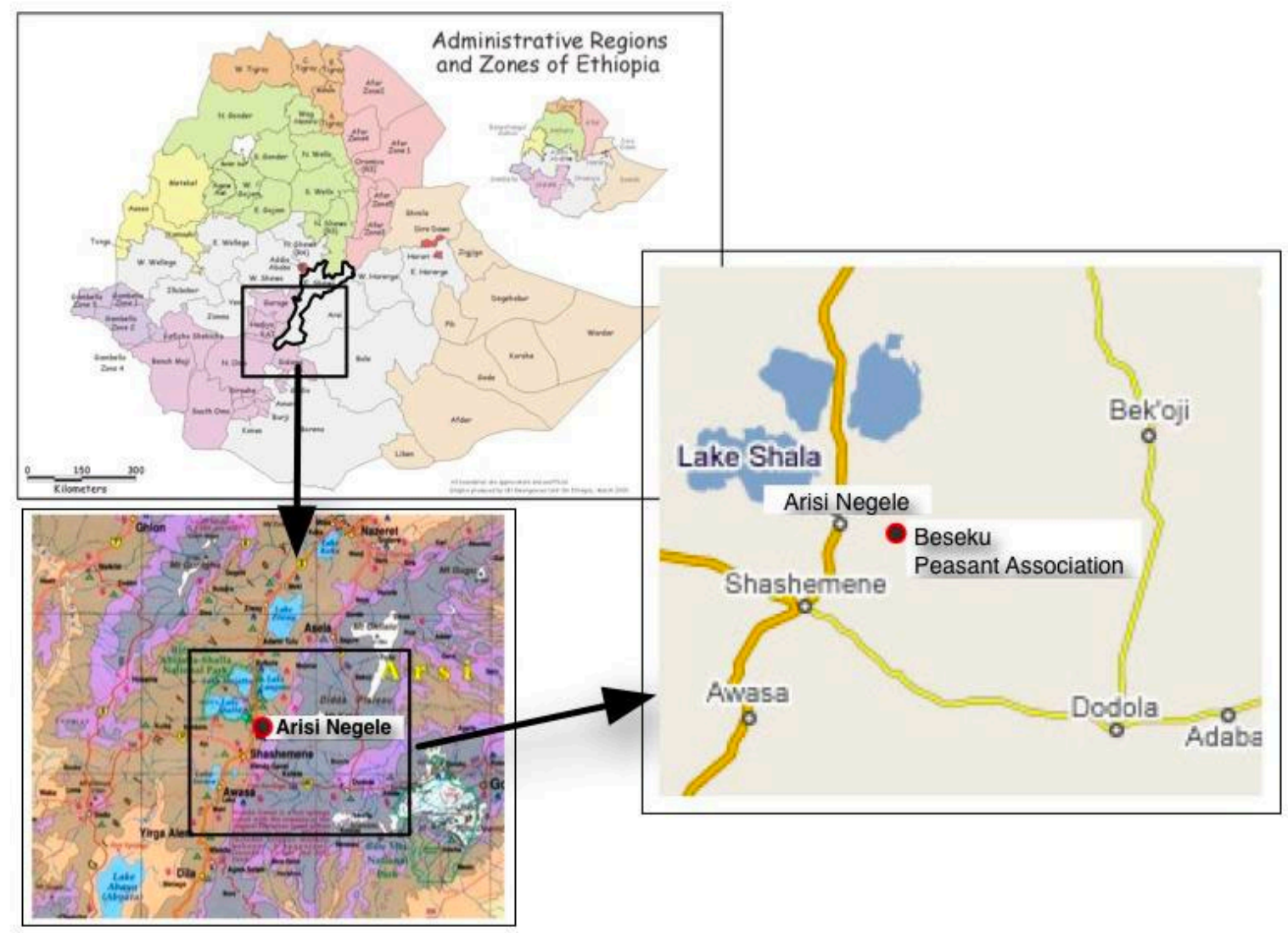

Figure 1: Study Site 
About fifty years ago, the larger part of Beseku was covered by forests and open grazing land. Due to population growth, most of the areas which formerly were covered by forests have been converted to cropland. Cropland agriculture has now become the dominant livelihood for farmers in the area (Karltun et al., 2008; Chiwona-Karltun et al., 2009).

\section{Data collection}

A cross sectional survey was conducted for a period of two months, from January February 2009. Three Gotes were selected for the study. Two of the Gotes, Shibeshi Gasha 1 and Shibeshi Gasha 2, had not reintroduced bean growing. Farmers who were living in the third Gote called Boye, had started growing beans. The Gotes were selected on the basis of earlier findings as the study was part of an ongoing project in the area. According to the peasant association household lists, there were 34 registered households in Shibeshi Gasha 1 and Shibeshi Gash 2, respectively, and 30 households in Boye Gote.

The study respondents were selected based on purposive sampling. Key informants with special knowledge about bean theft were identified. Subsequent respondents were identified using the snowball technique which utilizes subjects who may be able to recommend other potential candidates for the study (Bernard 2000). In addition to this, women, men, youth, local institution leaders and peasant association administrators were also interviewed as they were regarded as possessing relevant knowledge for answering the research question.

Qualitative and semi-quantitative data collection approaches were utilized in the study. Qualitative data collection methods were used to get a better understanding of complex and sensitive realities from the respondents' perspective (Mayoux, 2006; Kvale, 1996). Individual interviews, key informant interviews, and focus group discussions were the main methods of data collection in this study. All individual and key informant interviews were face to face interviews, administered by the researcher together with the field assistant. This was a useful method to address a sensitive issue, like bean theft, in the locality (Bernard 2000). The questionnaire was pre-tested prior to administering by translating all questions to the local language and by discussing the questions with the field assistant and some key informants. Interpretation of the questions is one of vital importance for the accurate solicitation of responses from the interviewees (Nichols 1991).

Transect walk: Prior to conducting interviews and focus group discussions, transect walks with local institutional leaders, local supervisors, and the field assistant were carried out in all three Gotes. It took us two hours in each Gote. Transect walks were conducted to observe special peculiarities of the study area, people, crop farms and other natural resources. Moreover, it helped in understanding the perceptions of local institutional leaders about their community, natural resources, land use, cropping system and vegetation. 
In-depth interviews: In-depth interviews were comprised of closed and open-ended interview questions that were based on earlier findings in the area related to bean theft. Open ended questions were included to give opportunity to the interviewees to bring up their own ideas and thoughts that may have not been included in interview (Nichols 1991; Willis, 2006). Each interview lasted approximately 30-50 minutes.

Key informant interviews: Key informant interviews were administered with members of the community that had good knowledge about problems of bean theft in the area. Key informants were men, women, youth, elderly, as well as notable members of the community. Indepth interviews were carried out to obtain a deeper understanding, that is, the 'how and why', based on the qualitative interviewing principles of Rubin and Rubin (2006, p. 3), of the sociocultural dynamics of bean theft and its impact on farmers. Each key informant interview lasted approximately one hour.

Likert scale questionnaire: Although specific statistical results are not reported in this article, the study itself used a Likert Scale-based questionnaire to measure respondents' attitudes toward bean theft. Both positive and negative statements (Cauvery, Sudhanayak, \& Meenakshi, 2003) related to bean theft were produced with a range of choices, including strongly agree, agree, neutral, disagree and strongly disagree. These were adapted to the local language for better cultural understanding. The variables and statements were based on previous study findings (Bernard, 2000).

Focus group discussions: Focus group discussions were conducted in all the three study areas. In order to give freedom to talk openly (Nichols, 1981; Dawson et al, 1993), separate women and men focus group discussions were held. Participants were local institution leaders and community members such as elderly, men, women and young people. A focus group discussion provides the opportunity to assess group consensus and the differing opinions and views of respondents (Pratt \& Loizos, 1992; Lloyd-Evans, 2006). On average, both women and men focus group discussions lasted 1- 2 hours. In all focus group discussions, the author moderated the discussion by using a checklist. General questions were used to introduce the topic and to encourage wide discussions (Dawson, Manderson, \& Talle, 1993).

\section{Data analysis}

Content analysis (Taylor-Powell \& Renner, 2003) and descriptive statistical methods were used to analyze qualitative and quantitative data, respectively. The sources of the data were interviews and focus group discussions. Open-ended questions from interviews and focus group discussions produced words, statements, phrases and paragraphs of text. In the course of data analysis, recorded interviews and focus group discussions were subjected to transcription. After 
transcription, themes and issues that arose during the discussions and interviews were identified, assembled, organized and coded in a meaningful way (Lloyd-Evans, 2006). This enabled the researcher to achieve a more accurate interpretation to the data (Alvesson \& Sköldberg, 2000; Cauvery et al., 2003).

\section{Results}

\section{Social characteristics of sampled households}

For the in-depth interviews, 22 respondents were selected from 68 households in Shibeshi Gash 1 and Shibeshi Gash 2 Gotes, with ages ranging from 19 to 69 years. In addition to these, 12 key informants were interviewed. Six focus group discussions were administered in three Gotes. Four focus group discussions (two men and two women) were conducted in Shibeshi Gash 1 and Shibeshi Gash 2 Gotes. Two focus group discussions (men and women) were carried out in the Boye Gote. This was for comparison purposes. In each group, 4-8 respondents participated in the discussions.

The number of women respondents was less compared to men in both individual and key informant interviews. It was not feasible to include many women in the study due to their domestic work, such as taking care of children, cooking food, fetching water, and going to market. And also, it is noteworthy to mention, some refused to be interviewed.

\section{Drivers of bean theft}

During the interviews and discussions, many respondents claimed that poverty was one of the main drivers of bean theft. A key informant stated that land shortage and unemployment were leading to poverty and that poverty, in turn, led to theft.

\section{Women and bean theft}

Some farmers in Shibeshi Gasha Gotes said they received the information package, including bean seeds. These farmers were mostly male farmers belonging to the male Iddirs. However, none of them planted any beans in their residential area; some even refused to receive beans while those that received bean seeds planted them in other villages. "Why do you think I bought land in another area to cultivate beans if there is no theft in this area?', one male respondent answered during an individual interview.

The study revealed that women in Shibeshi Gasha Gotes were not included in the information and distribution of bean seeds during the first round in Beseku. However, they had heard about it and learned from their husbands and neighbors about the programme. Another 


\section{The Impact of Faba Bean Theft in Rural Ethiopia - Zekiwos-Gichamo, Karltun, Tolera, and Chiwona-Karltun}

point is that women are the ones who are supposed to prepare meals for the family. They stated that they were selling large amounts of wheat and maize to buy small amounts of beans at high prices. Bean flour is vital to cook sauce to eat with Enjera (Ethiopian food). If they do not have enough crops to sell in the market, they will not be able to buy beans in return. Moreover, most women indicated that they did not have equal decision-making power with men as to whether or not they should grow beans. As they stated, men are the ones who decide this most of the time. In one key informant interview, a widow mentioned that she divided a large part of the family land to her sons and she was left with only a small portion of land which was not enough to cultivate beans and other crops.

\section{Factors affecting adoption of bean reintroduction}

In one of the study areas called Boye, farmers were growing beans. The findings showed that these farmers live close to their farms. Villagization, which is a government resettlement policy, had not been implemented in their Gote. As they stated, it was possible to guard their farms because their farms were near to their homes. Moreover, all women and men participated in the formulation of the by-laws through their Iddir. On top of this, unlike the Shibeshi Gasha 1 and Shibeshi Gasha 2 Gotes, they were from the same ethnic group. Another point that participants raised during the focus group discussion was that they had good consultations amongst themselves concerning bean theft and the reintroduction of beans.

\section{Villagization}

Villagization is the concentration or clustering of rural populations in villages or small towns. Respondents pointed out that they used to grow beans before they were moved to other areas by villagization during the Derge Regime, which was in power from 1974 to 1987, immediately following the removal of Emperor Haile Selassie I. The Derge regime imprisoned and murdered thousands of its opponents. Almost all respondents mentioned that villagization was a major factor that exacerbated the problem of bean theft because many now live far from their farm fields. Respondents also stated that maize is the staple food crop for the area; however, maize has also not been spared from theft. Maize theft is a recent phenomenon in the area, and farmers indicated that weak law enforcement is contributing to this new form of theft.

\section{Fear of conflict}

The issue of conflict arose as another factor hindering the growing of faba beans. Farmers said that there is fear of conflict between neighbours, different tribes, and even between families and relatives, especially when confronting the thieves. One respondent indicated that: 
"Most people do nothing when they see a thief while stealing, they do not want to quarrel with the person who is stealing. This is fear of creating an enemy in the future. They think that the thief will come to steal from their farm in the future as revenge. So they prefer not to say anything', (Source: Individual interview, Beseku Ilala Peasant association, Feb 2009)

One special feature of the area compared to the other nearby Gote is the mix of ethnic tribes living in the area. Some respondents explained that they do not have unity and trust like the other Gote. When asked 'why?' the answer was "we are mixed tribes".

However, one could see different opinions and thoughts about this issue. In focus group discussions, some participants indicated that there are thieves in both tribes. The problem was that they do not expose/report thieves to village authorities or law enforcement. If they do, they believe, thieves will take revenge on them in the future. As a result, they prefer not to expose thieves. Most interviewees indicated that enforcement of government law is very weak and as a result the problem is not solved.

The issue of trust and unity among the residents rose repeatedly during interviews and focus group discussions. An individual interviewee stated: "in this area people do not trust each other, so we do not grow faba beans" (Source: key informant interview, Beseku Peasant association, Feb 2009). Another point that arose in discussions and interviews was that men were afraid to catch women when they found women stealing from their farm. This is because they are afraid women will allege or claim it was an attempt to rape them. What the men do is to leave them (the women) on their farm. However, this might lead to conflict between the owner of the farm and the wife. Also, some respondents mentioned that the thieves were often identifiable and they usually were someone's children from the area. Almost all respondents agreed that thieves are insiders, making it more difficult to report incidents to what they believe is ineffective law enforcement. Hence, reporting brings only adversity.

\section{Land holding, population and migration}

Most people in the study area were dependent on livestock production for their livelihood but with time this had changed due to population pressure. Through time they started mixed agriculture, both crop production and livestock production. In order to expand cropland, people cleared previously forested land. Respondents said that as the number of population increased from day to day, the land holding became smaller and smaller. Most farmers mentioned that they have less than one hectare of land.

Migration of people from other areas in search of land is also another factor for increased number of people and small landholdings in the area. Some respondents indicated that they 


\section{The Impact of Faba Bean Theft in Rural Ethiopia - Zekiwos-Gichamo, Karltun, Tolera, and Chiwona-Karltun}

moved from the northern part of Ethiopia. Some people pointed out that they are interested in growing faba beans, but due to small landholding, they are not growing it. They mentioned that they prefer to grow maize, the staple food, or wheat rather than faba beans.

\section{Discussion}

\section{Tolerated theft}

People's perceptions and attitudes toward theft and the amount that they steal determine how the problem is perceived. This study showed that in the past taking small amount of beans from someone's field to satisfy their hunger was not regarded as theft. Rather, it was considered sharing with those who were in need and those who could not grow beans on their own. There is a locally acknowledged proverb which supports bean sharing, which, in the local language is:

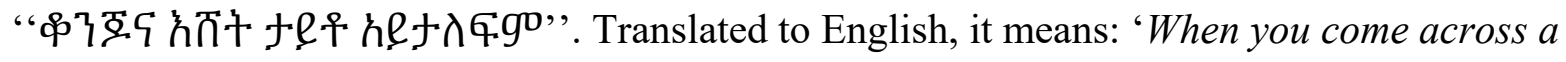
bean field or a beautiful woman you cannot pass by without enjoying'. Hence, sharing a reasonable 'snack tasting' amount of bean was a socially acceptable habit. But now it is beyond tasting. People are poaching beans not only because they are hungry but also to sell in the market. Over time, it has become a way of gaining an economic benefit at the expense of the farmers who are growing the beans. However, some respondents disagreed and remained steadfast in their belief that this behavior has not moved beyond tasting/satisfying hunger.

This finding is similar with the Blurton Jones (1987), Bliege Bird and Bird (1997) and Hawkes' (1993) work on tolerated theft, which is food sharing. These findings showed that successful foragers share with unsuccessful foragers based on consumption needs which follows a diminishing marginal return curve. In order to share, the cost of not sharing should be higher than sharing with others.

\section{Drivers of bean theft}

Youth unemployment is seen as one of the drivers of bean theft in the area. As pointed out by Ashford (2007), the population of Sub-Saharan Africa is very young, accounting for 44 percent of the total population. In Ethiopia, the dependency ratio, the proportion of the total the population under age 15 and above age 65 years in relation to the productive age of 15-64, is 85percent (MFED 2007). This indicates a high dependency burden.

The main source of employment is agriculture in the most rural regions of Ethiopia in agriculture (DFID 2004). However, due to migration and high birth rates, landholdings are very small. In addition to this, land inheritance happens when the father dies and smaller pieces of land are distributed among the children. Small landholdings are unsustainable and often insufficient for a whole family. Moreover, rural formal sector employment is very low and 
cannot employ excess labour. There is a lack of diversity of income sources, such as on-farm and off-farm activities in the area. These are a contributing factors for high youth unemployment.

The price of beans in the market is high, which is an incentive for youth to steal and sell stolen beans. In Ethiopia the current price of bean is approximately 1500 birr (the Ethiopian currency) with 15 birr per kilogram of faba beans (2.205 pounds) equal to .54 US dollar. The International Poverty Line for absolute poverty set by World Bank is 1 dollar per day. Hence, selling one kilogram of beans means a lot. Clearly, increased population leads to more unemployment, more unemployment creates more poverty, and all of this leads to more theft of faba beans, maize and other agricultural crops and animals.

\section{Women, bean theft and bean adoption}

Information sharing concerning bean reintroduction was selective; women did not have access to participate in the formulation of the by-laws and for getting bean seeds in either Gote. If you are a man, however, you were likely to be informed. The men were the ones who formulated the by-laws though the men's Iddir. The problem goes back to lack of women participation in important decision-making and poor access to productive assets (Ellis, 2000). This shows that the women's position is different from men's in their power to decide to stop bean theft, and whether or not to grow faba beans. Moreover, men are the ones who decide which crop to grow in both home gardens and farm fields. Around the world, especially in rural areas, women are often excluded from decision-making processes that affect their own lives (Runyan \& Peterson, 2014) and have less access to resources compared to men (Jackson, 1999).

Similarly, Moser and Young (1981) argued that there is a gender difference in resource control and decision making power. A study carried out in West Africa showed that the men are the ones who make the decision to buy agricultural inputs. This is due to the socio-cultural norms that it is not acceptable for women to decide together or collaboratively with men (IFAD, 1998).

\section{Poverty and Land Scarcity}

Due to scarce availability and high price of beans in the marketplace, the poor cannot afford to buy seeds. As a result, the poor were not able to cultivate beans on their farm. This shows that poor and marginalized groups, especially women, are always at greater risk (Dercon, 2006). The only alternative that they have is to sell other crops to buy beans.

People who have money were buying or renting land in other areas where bean cultivation is feasible. Selling and renting land have also contributed to the current problem. When people sell land, they will be either landless or have only a small amont of land left. In turn, it leads to poverty and they resort to stealing, creating a vicious cycle. However, it is worthwhile to 


\section{The Impact of Faba Bean Theft in Rural Ethiopia - Zekiwos-Gichamo, Karltun, Tolera, and Chiwona-Karltun}

mention that buying and selling land is forbidden by the current Ethiopian government. According to the Federal Democratic Republic of Ethiopia Constitution, which was adopted on December 1994, land is owned by the state and the people of Ethiopia (FDRE, 1995). Tenants have no right to sell, exchange and mortgage their land except what is provided for in usage rights. All rural and urban land is under state ownership. The buying and selling of that was mentioned by respondents is contrary to current government land policy.

\section{Factors affecting adoption of bean reintroduction}

To be successful in adoption of bean reintroduction, one needs certain pre-conditions, namely social cohesion, trust, prior discussion and consideration of the topic, and a commitment to act according to the by-laws of the Iddir. In addition to this, participation of women in the decision making process has a great potential in achieving the intended goal.

\section{Villagization}

Before the downfall of Emperor Haile Selassie, land was owned by landlords. Moreover, in 1974 there was a great famine in the country. In response, in 1975 the new government framed a land reform policy. This land reform proclamation of 1975 during the Derge Regime, included the policy of villagization (Ofcansky and Berry, 1991). Villagization was the clustering of people into villages and the moving of some farmers to other regions. The government ostensibly used this strategy to make public services more accessible (Steingraber, 1987).

Although the state had good intentions with villagization, it wrought great disharmonization. It laid the groundwork for the current problem with faba beans and other forms of agricultural theft. Farmers' crop fields and pasturelands are now often far away from their homes. This makes it quite difficult to guard their farms, leaving them exposed to predatory animals, birds who eat the seeds, and thieves. Anyone who passes by can steal beans, because there no one there to guard the farm.

This finding agrees with the Ofcansky and Berry (1991) study. They explained how villagization affected farmers by increasing the distance between home and farm. Farmers have to travel long distances to reach their farms which is considered 'wasting time and effort'. The statement 'wasting time and effort' means just that: Why invest in something that does not pay for the amount of effort involved?

The study by Steingraber (1987) in the southwest Ethiopia supports this finding. It has showed that due to villagization, the farmland is often far away from the places where farmers reside. Moreover, Steingraber (1987) criticized resettlement and villagization program, as it had political motives behind the program more so than a goal of positive rural development. 


\section{Conflict or harmony}

This study has shown that people who are living in the study area were not secure due to a lack of a functional welfare state. It is the same in many other low-income countries, which are trapped by bad governance and policies (Collier 2007).

Traditionally, the old outweigh the young in decision-making and setting policies in local institutions. In the past, rules, which were conveyed by elders, were respected and accepted. However, new generations do not want to accept traditional laws. They know government rules because of school and they know how to use them. That is why they were released after a few hours or a few days from police stations when they were detained for suspicion of thievery. According to government laws, if there is no evidence that shows that a thief is guilty, there is no case and therefore no punishment. In order to accuse someone, there must be witnesses. If there is no one with the accuser when someone is seen stealing from a farm field, the farmer is not able to accuse the thief because under the law a person cannot be both the witness and the accuser at the same time. As the field is often now far away from the farmer's residence, it becomes much more difficult, if not impossible, to find witnesses.

Another problem is that people do not expose thieves due to fear of future revenge. This finding is similar with the studies of Aaron Brooks (1986) and Schechter (2007). Aaron Brooks (1986) stated that farmers do not take any legal action against crop thieves because thieves could come and take revenge. Similarly, the study by Schechter (2007) showed that most farmers did not report to the police, due to fear of revenge by the accused. Also, the worst thing is that thieves might be their own children, who steal for cash to buy things. How easy is it to give one's own children to police, especially when the police are perceived as ineffective?

\section{Land holding, population and migration}

The population is increasing because of high birth rates. In return, landholdings are decreasing through time because of increasing population. The landholdings of most farmers is already less than one hectare, which was another factor which hindered faba bean cultivation in the study area. As a result, farmers prefer to grow maize or wheat. Some youth are landless and also they are not engaged in off-farm employment activities. The study in the same area by Chiwona-Karltun et al (2009) indicated that less availability of land was the factor for crop changing pattern, including faba beans. Similarly, Gebreselassie (2006) stated that most rural Ethiopian farmers are characterized by small landholdings. Small landholding leads to shortening of crop rotation, as a result, soil quality and soil fertility is decreasing (Gebreselassie, 2006). 
Migration of people in search of land and opportunity has its own contributions to the current problem. Migration, from the northern part of Ethiopia through resettlement programs during the Derg regime also had a negative effect on the amount of landholding in the area (Ofcansky \& Berry, 1991). The indigenous people did not and continue to dislike many of the newcomers because land is a priced commodity and major resource for their livelihood, reflecting a worldwide problem associated with migration of peoples in a globalized economy (United Nations, 2017).

\section{Conclusions}

This study has shown that bean theft is affecting the livelihood of the people in Ethiopia. In addition to this, different factors which affect the cultivation of faba bean have been found in this study. Moreover, the study dealt with the role of local institutions in rural Ethiopia in affecting agricultural practices and thereby the economic well-being of a family. It tried to address how food security and economic activities can be enhanced or even discouraged by the long-held and respected tacit rules that are overseen by local institutions which hold a decisive position in rural Ethiopia. However, government intervention in conflict management in locally accepted way is seen as crucial.

\section{Endnotes}

${ }^{1} \mathrm{~A}$ pulse is the edible part of a legume plant. A legume is any kind of plant that is a grain with a seed pod that can be opened on either side. They are important in crop rotations because of their nitrogen-fixing chareacrteristics, and are useful for both human and animal feed. Common legumes include alfalfa, clover, peas, beans (including faba beans) and peanuts.

${ }^{2}$ Research project "Making soil quality last - participatory soil fertility management in the highlands of Ethiopia' funded by SIDA-SAREC (Swedish International Development Cooperation Agency-Sustainable Agriculture Research and Extension Center).

${ }^{3}$ Vicia faba is the scientific name of the faba bean.

${ }^{4}$ Gote is a local name for a collection of 30-34 households. 


\section{References}

Aaron Brooks, F.J. (1986). Good fences make good neighbours: Trespass at the urban fringe. Culture and Agriculture, 7(30), 1-6.

Adal, Y. (1999). Rural organizations in Ethiopia: Their conditions and role in sustainable natural resource use and enhancing food security. In T. Asefa (Ed.), Food security through sustainable land use: policy on institutional, land tenure and extension issues in Ethiopia (pp. 293-304). Addis Ababa: OXFAM Novib Partners Forum on sustainable land use. Addis Ababa.

Agegnehu, G., Ghizaw, A., \& Sinebo, W. (2006). Yield performance and land use efficiency of barley and faba bean mixed cropping in Ethiopian highlands. European journal of Agronomy, 25, 202-207. https://doi.org/10.1016/j.eja.2006.05.002

Alvesson, M and Sköldberg, K. (2000). Reflexive methodology: new vistas for qualitative research. London: SAGE Publications.

Amanuel, G., Kühne, R.F., Tanner, D.G., \& Vlek, P.L.G. (2000). Biological nitrogen fixation in faba bean (Vicia faba L) in the Ethiopian highlands as affected by P fertilization and inoculation. Biology and Fertility of Soils, 32, 353-359. https://doi.org/10.1007/s003740000258

Ashford, L. (2007). Africa's youth population: Risk or opportunity? Washington, D.C.: Population Reference Bureau USAID. [On line]. Available at: http://www.prb.org/pdf07/AfricaYouth.pdf [accessed 2 April 2009]

Bernard, H. (2000). Social research methods: Qualitative and quantitative approaches. Thousand Oaks, CA: SAGE Publications, Inc.

Beseku Peasant Association, (2009). List of households in Beseku Illala Peasant Association. Beseku, Ethiopia.

Bliege Bird, R.L, \& Bird, D.W. (1997). Delayed reciprocity and tolerated theft: The behavioural ecology of food sharing strategies. Current anthropology, 38(1), 49-78. https://doi.org/10.1086/204581

Blurton Jones, N. (1987). Tolerated theft, Suggestion about the ecology and evaluation of sharing, hoarding and scrounging. Social Science Information, 26(1), 31-54. https://doi.org/10.1177/053901887026001002 
Cauvery, R., Sudhanayak, R., \& Meenakshi R. (2003). Research methodology. New Delhi: S. Chand and Company LTD.

Chiwona-Karltun, L., Tylleskär, T., Mkumbira, J., Gebre-Medhin, M., \& Rosling, H. (2000). Low dietary cyanogen exposure from frequent consumption of potentially toxic cassava in Malawi. International Journal of Food Sciences and Nutrition, 51, 33-43. https://doi.org/10.1080/096374800100886

Chiwona- Karltun, L., Mulugeta, L., Tolera, M., Berisso, T., \& Karltun, E. (2009). Soil fertility and crop theft: Changing rural dimensions and cropping pattern. Report presented at The Seasonality Revisited International Conference. Brighton: Institute of Development Studies.

CIAT (International Centre for Tropical Agriculture). (2008). Evaluating marketing opportunity for haricot beans in Ethiopia. Available at: www.ipms-ethiopia.org/.../WP7Haricot_beans_marketing_in\%20Ethiopia.pdf [accessed 8May 2009].

Collier, P. (2007). The bottom billion: why the poorest countries are failing and what can be done about it. Oxford: Oxford University Press.

CSA (Central Statistical Agency of Ethiopia). (2008). Summary and Statistical Report of the 2007 Population and housing Census Results. [On line].Available at: http://www.csa.gov.et/pdf/Cen2007_prelimineray.pdf [accessed 11 December 2008].

Dawson, S., Manderson, L., \& Tallo, V.L. (1993). Manual for the use of focus groups. Boston, MA: International Nutrition Foundation for Developing Countries (INFDC).

Dercon, S. (2006). Vulnerability: A micro perspective. QEH Working Paper Series- QEHWPS 149. Oxford: Queen Elizabeth House, University of Oxford.

DFID (Department for International Development, UK). (2004). Rural and urban development case study-Ethiopia. Oxford: Oxford Policy Management.

Duc, G., Bao, S., baum, M., Redden, B., Sadiki, M., Suso, J., Vishniakova, M., \& Zong, X. (2008). Diversity maintenance and use of Vicia faba L. genetic resources. Field Crops Research, 115(3), 270 -278. https://doi.org/10.1016/j.fcr.2008.10.003

Ellis, F. (2000). Rural livelihood and diversity in developing countries. Oxford: Oxford University Press. 
Fafchamps, M. \& Minten, B. (2003). Theft and rural poverty: results of a natural experiment. Proceeding of the $25^{\text {th }}$ International Conference of Agricultural Economics (IAAE). Durban, SA.

FDRE (Federal Democratic Republic of Ethiopia). (1995). The Constitution of the Federal Democratic Republic of Ethiopia, Addis Ababa: Federal Negarit Gazetta.

FDRE (Federal Democratic Republic of Ethiopia) (1997). Rural land administration proclamation of the Federal Government of Ethiopia. Proclamation No. 89/1997. Addis Ababa: Federal Negarit Gazetta.

Fufa B., \& Hassan M. (2006). Determinants of fertilizer use on maize in Eastern Ethiopia. A weighted endogenous sampling analysis of the extent and intensity of adoption. Agrekon (Agricultural Economics Research, Policy and Practices in Southern Africa), 45(1), 3849. https://doi.org/10.1080/03031853.2006.9523732

Gebreselassie, S. (2006). Land, land policy and smallholder agriculture in Ethiopia: Options and scenarios. Paper prepared for the Future Agricultures Consortium meeting at the Institute of Development Studies 20-22 March 2006. London.

Hawkes, K. (1993). On why male foragers hunt and share food: Reply to Hill and Kaplan. Current Anthropology, 34(5): 706-710.

Hundie, B. (2010). Conflicts between Afar pastoralists and their neighbors: Triggers and motivations. International Journal of Conflict and Violence, 14(1), 134-148.

Howard, J.A., Said, A., Molla,D., Diskin, P., \& Bogale, S. (1995). Toward increased domestic cereals production in Ethiopia. Using a commodity systems approach to evaluate strategic constraints and opportunities. Addis Ababa \& East Lansing, MI: Ministry of Economic Development and Cooperation and the Michigan State University Food Security Research Project. Available at: www.aec.msu.edu/fs2/ethiopia/wp3.pdf [accessed 12 January 2010]

IFAD (International Fund for Agricultural Development). (1998). Agricultural implements used by women farmers in Africa. Rome: IFAD.

Jackson, C. (1999). Men at work. Bonn: European Association of Development Research and Training Institutes. 
Karltun, E., Röing de Nowina, K., Chiwona-Karltun, L., \& Berisso, T. (2008). Working with farmers and local institutions to improve soil quality in sub-Saharan Africa.Currents, 43, 7-11. Available at: http/www.info.slu.se/currents/2008/currents43 [accessed 12 October 2008].

Kvale, S. (1996). An Introduction to qualitative research interview. London: SAGE Publications Ltd.

Lindemann W., \& Glover C. (2003). Nitrogen Fixation by legumes. Las Cruces: New Mexico State University, Cooperative Extension Service. Available at: www.cahe.nmsu.edu/pubs/_a/a-129.pdf [accessed 12January 2010]

Lemenih, M. (2004). Effect of land use changes on soil quality: native flora degradation and restoration in the highland of Ethiopia. Implications for sustainable land management. Uppsala: Swedish University of Agricultural Sciences, Department of Forest Soil.

Lloyd-Evans, S. (2006). Focus groups. In V. Desai and R. Potter (Eds). Doing development research (pp. 153-162). London: SAGE Publications Ltd. https://doi.org/10.4135/9781849208925.n16

Mammo, T. (1999). The paradox of Africa's poverty: The role of indigenous knowledge, traditional practice and local institutions. Trenton, NJ: The Red Sea press.

Matthews, P. \& Marcellos, H. (2003). Faba bean. Agfact P4.2.7. Wagga Wagga, NSW: Division of Plant Industries.

Mayoux, L. (2006). Quantitative, Qualitative or participatory? Which method, for what and when? In V. Desai and R. Potter (Eds), Doing development Research (pp. 115-129). London: SAGE Publications Ltd. https://doi.org/10.4135/9781849208925.n13

MFED (Ministry of Finance and Economic Development) (2007). Ethiopia population images 2006. Addis Ababa: Ministry of Finance and Economic Development.

MoARD (Ministry of Agriculture and Rural Development, Federal Democratic Republic of Ethiopia). (2003). Faba Bean Development Plan. Addis Ababa: The Ministry of Agriculture and Rural Development. Available at: www.moa.gov.et [Accessed 19 November 2010]. 
MoARD (Ministry of Agriculture and Rural Development, Federal Democratic Republic of Ethiopia). (2010). Ethiopia's agricultural sector policy and investment framework. Addis Ababa: The Ministry of Agriculture and Rural Development

Moser, C., \& Young, K. (1981). Women of the working poor. Institute of Development Studies Bulleton, 12(3), 54-62. https://doi.org/10.1111/j.1759-5436.1981.mp12003010.x

Muehlbauer F., \& Tullu A. (1997). Vicia faba L. West Lafayette, IN: Purdue University, Center for New Crops and Plant Products. Available at: www.hort.purdue.edu/newcrop/CropFactSheets/fababean.html -United States [accessed 05 June 2009]

Nichols, P. (1991). Social survey methods: a field guideline for development works. Oxford: Oxfam GB.

Ofcansky, T., \& Berry, L. (1991). Ethiopia: a country study. Washington, D.C.: US Library of Congress, Federal Research Division. [On line] Available at:http://countrystudies.us/ethiopia/45.htm. [accessed 15 March 2009]

Pankhurst, A., \& Mariam, D.H. (2000). The Iddir in Ethiopia: Historical development, social function, and potential role in HIV/AIDS prevention and control. Northeast African Studies, 7(2), 35-57. https://doi.org/10.1353/nas.2004.0018

Pankhurst, A. (2001). Conflict management over contested natural resources: A case study of pasture, forest and irrigation in South Wello, Ethiopia. Madison: University of Wisconsin-Madison, BASIS - Assets and Market Access and Collaborative Research Support Program.

Pratt, B., \& Loizos, P. (1992). Choosing research methods: Data collection for development workers. Development Guidelines No.7. Oxford: Oxfam UK and Ireland. https://doi.org/10.3362/9780855986803

Rubin, H and Rubin, I. (2005). Qualitative interviewing: the art of hearing data. London: SAGE Publication, Ltd. https://doi.org/10.4135/9781452226651

Runyan, A., \& Peterson, V.S. (2014). Global gender issues in the new millennium (4 ${ }^{\text {th }}$ ed.). London: Routledge.

Shakesheff, T. (2002). Wood and crop theft in rural Herefordshire, 1800-60. Rural History, 13 (1), 1-17. https://doi.org/10.1017/S0956793302000213 
Steingraber, S. (1987). Resettlement and Villagization - Tools of Militarization in S.W. Ethiopia, Cultural Survival Quarterly, Vol. 11, No. 4.

Schechter, L. (2007). Theft, gift-giving, and trustworthiness: Honesty is its own reward in rural Paraguay. The American Economic Review, 97(5), 1560-1582. https://doi.org/10.1257/aer.97.5.1560

Scott, J C. (1985). Weapons of the Weak: Everyday Forms of Peasant Resistance. New Haven: Yale University Press.

Sundberg, N. \& Ostrom, K. (1982). Migration and welfare: a study in Northern Sweden. Geografiska Annaler. Human Geography. 64(2), 153-160. https://doi.org/10.1080/04353684.1982.11879483

Taylor-Powell, E. \& Renner, M. (2003). Analyzing Qualitative Data. Madison: University of Wisconsin-Madison, Cooperative Extension.

Tolera, M., Asfaw, Z., Lemenih, M., \& Karltun, E. (2008). Woody species diversity in a changing landscape in the south central highlands of Ethiopia. Agriculture Ecosystems and Environment, 128(1-2), 2-58. [On line]. https://doi.org/10.1016/j.agee.2008.05.001

United Nations (2017). International migration report 2017. New York: United Nations, Department of Economic and Social Affairs. Available at: http://www.un.org/en/development/desa/population/migration/publications/migrationrepo rt/docs/MigrationReport2017_Highlights.pdf [accessed 6 June 2018].

USDA (United States Department of Agriculture). (2005). Forces shaping food security: Factors affecting production. Food security assessment / GFA-16. Washington, D.C.: USDA, Economic Research Service. Available at: www.ers.usda.gov/publication/[accessed 10 may 2009].

Willis, K. (2006). Interviewing. In V. Desai and R. Potter, (Eds.), Doing development research (pp. 144-152). London: SAGE Publications Ltd. https://doi.org/10.4135/9781849208925.n15

Wolde-Giorgis, O. (1999). Land tenure and institutional capacity. In T. Asefa (Ed.), Food security through sustainable land use: Policy on institutional, land tenure and extension issues in Ethiopia (pp. 293-304). Addis Ababa: NOVIB Partners Forum on Sustainable Land Use. 
International Journal of Rural Criminology, Volume 4, Issue 2 (June), 2019

Wood, G. \& Gough, I. (2006). A comparative welfare regime approach to global social policy. World Development, 34(10), 1696-1712. https://doi.org/10.1016/j.worlddev.2006.02.001 